\title{
Aeromoniasis Induced Protein and DNA and Histological Alterations in the muscle tissues of Labeo rohita.
}

\author{
Satyalatha B. D.J ${ }^{1}$ and Viveka Vardhani. $V^{2}$ \\ 1,2 Department of Zoology Acharya Nagarjuna University Nagarjunanagar - 522510.
}

\begin{abstract}
The present study was conducted to estimate the level of protein and DNA and to know the pathoghencity of Aeromonas liquefaciens in the muscle tissues of the experimentally infected fish. Four different serial concentrations, vide $10^{-2}$ (Group A), $10^{-4}$ (Group B), $10^{-5}$ (Group C) and $10^{-6}$ (Group D), CFU/fish of the bacteria were injected intramuscularly in each of the four groups of 44 fish in each group (age 5-6 months, approximately $75 \mathrm{gm} w t)$. A total of 44 fish of same age and weight in each group a,b,c and $d$ were used as controls for comparison. Necropsies were made (6 fish from each group) on hour 1, 3, 6, 12, 18, 24, 36, 48,72, 96 and 216 of infection from each of the infected group and controls for the estimation of total protein and DNA and for histological changes. There was a significant decrease of muscle protein in groups $A$ and $B$ and increase in group $D$ when compared with controls. Also there was a significant increase of DNA in comparison with controls. It was understood that the virulent pathogen caused much physiological changes in the level of protein and DNA and histopathological changes.
\end{abstract}

\section{Introduction}

Aeromonas infections are causing septicemia and great economic losses in fish culture worldwide (Holliman, 1993). In many cases, fish may resist the bacterial disease by developing resistance (Ansary et al., 1992; Pettibone et al., 1996; Son et al., 1997; Vivekanandhan et al., 2002). Hemorrhagic septicemia is a common bacterial disease caused by Aeromonas species (Bullock et al., 1971; Khardori and Fainstein, 1988). The stress-mediated disease, aeromoniasis is also described as a ulcerative disease of fish (Karunasagar et al., 1995). Aeromonas bacteria may cause hemorrhagic septicemia, epizootic ulcerative syndrome (EUS) and abdominal dropsy to fishes (Freriches, 1989; Das and Mukherjee, 1998). A. hydrophila infection may bring scale sac edema, ascities, Exopthalmus and ulcers in diseased carps (Miyazaki et al., 2001 and Sahoo et al., 2004). Aeromoniasis in Indian major carps poses one of the major threats in aquaculture. Occurrence of skin lesions with hemorrhages due to A. hydrophila and the effective antibiotic treatment was reported in a carp (Cyprinus carpio) hatchery farm in Turkey (Adanir and Turutoglu, 2007). A. hydrophila is the causative agent of hemorrhagic septicemia or ulcer disease or red sore disease and is generally found in the gastrointestinal tract (Swann and White, 1989; Guz and Kozinska, 2004; Yildiz et al., 2005). Abnormal conditions of the pond environment like stress, over crowding, temperature fluctuations, poor water quality, high nitrite and carbon dioxide levels and mishandling of fish are found to be associated with disease outbreaks (Dixon and Issvoran, 1993; Aoki, 1999; Cipriano, 2001; Lakshmanaperumalswamy et al., 2005; Yildiz et al., 2005; Adanir and Turutoglu., 2007) isolated A. hydrophila from the skin, kidney, heart and liver of the carp (Cyprinus carpio) (in a hatchery form). In chronic aeromonial infections, both the dermis and epidermis are eroded and the underlying musculature becomes severely necrotic (Huizinga et al., 1979). Sloughing of scales at the site of infection with muscular hemorrhagic protuberance was recorded in Carassius auratus with A. hydrophila (Ramasamy et al., 2009). The biochemical characteristics like total protein and DNA and histopathological observations from muscles of healthy and/or diseased fish have not been described clearly. Hence, a new vista has been opened to study the alteration in the level of total proteins and DNA and histology of muscles of experimentally infected fish with varied doses of A. liquefaciens.

\section{Material And Methods}

Procurement of best fish, and the virulent A. liquefaciens and preparation of varied infective doses and route of infection was already described in previous paper (Satyalatha and Vardhani, 2014) protein and DNA content were estimated from muscle at hour 1,3,6,12,18,24,36,48,72,96 and 216 of experimental period from the four experimental groups and controls. Also muscle tissue was fixed, sectioned (5m u) and stained from histological changes. The significance of elevated level of protein and DNA content was tested by applying student ' $t$ ' test. 
Results are shown in table 1.

\section{Results And Discussion}

Protein activity : In group A, which received a heavy dose of A. liquefaciens $\left(10^{-2} \mathrm{CFU} / \mathrm{fish}\right)$, the level of protein on hour $1(68.27 \mathrm{mg} / \mathrm{ml})$ and $3(68.62 \mathrm{mg} / \mathrm{ml})$ is somewhat equal to that of controls $(68.91 \mathrm{mg} / \mathrm{ml} \mathrm{and}$ $68.89 \mathrm{mg} / \mathrm{ml})$. There was an increase on hour $6(70.0 \mathrm{mg} / \mathrm{ml})$. Again there was a decrease on hour $12(66.89$ $\mathrm{mg} / \mathrm{ml})$ and $18(67.93 \mathrm{mg} / \mathrm{ml})$. There is a gradual decrease of protein from hour 18 to 216; all these decreased values are found to be below normal values. Fish of group B, ( $10^{-4} \mathrm{CFU} /$ fish $)$ showed lower levels of protein throughout the experimental period when compared to that of uninfected controls. The level of total protein decreased from hour 1 to 216 in experimental group B when compared with controls (group b). The initial below normal value $(64.13 \mathrm{mg} / \mathrm{ml})$ decreased further by hour $24(64.13 \mathrm{mg} / \mathrm{ml})$ and rose again by hour 36 $(67.24 \mathrm{mg} / \mathrm{ml})$ but still below control level $(68.50 \mathrm{mg} / \mathrm{ml})$. The level of protein decreased gradually from hour $48(67.58 \mathrm{mg} / \mathrm{ml})$ to $216(62.41 \mathrm{mg} / \mathrm{ml})$. (In group C $10^{-5} \mathrm{CFU} /$ Fish) A slight increase of protein on hour 1 decreased to normal $(67.93 \mathrm{mg} / \mathrm{ml})$ and below normal $(66.89 \mathrm{mg} / \mathrm{ml})$ level on hour 3 and 6 . From hour 12 to 216 , a brisk increase of protein has taken place and reached peak value on hour $24(71.37 \mathrm{mg} / \mathrm{ml})$. This increase is higher than that of normal, untreated fish. From hour 36 to 216 a gradual decrease of protein level has taken place. However, this decrease is comparatively higher than that of protein value of controls. In case of group D, $\left(10^{-4} \mathrm{CFU} / \mathrm{fish}\right)$ on the hour $1(72.06 \mathrm{mg} / \mathrm{ml})$ of infection, the protein level is higher than the normal level $(68.93$ $\mathrm{mg} / \mathrm{ml})$ and it was stable even on hour 3 of infection. A peak level of protein was observed on hour 6 (73.10 $\mathrm{mg} / \mathrm{ml})$. From hour $12(71.72 \mathrm{mg} / \mathrm{ml})$ to $24(70.34 \mathrm{mg} / \mathrm{ml})$, a gradual decrease of protein level has taken place. The decreased protein value remained stable on hour $36(71.03 \mathrm{mg} / \mathrm{ml}), 48(71.03 \mathrm{mg} / \mathrm{ml})$ and $96(71.72$ $\mathrm{mg} / \mathrm{ml})$. From day 4 to $9(72.06 \mathrm{mg} / \mathrm{ml})$ there is a slight increase of protein. However, this increase is comparatively lower than that of peak value of protein. The protein values on hour 1 and day 9 are exactly equal.

DNA activity : Higher DNA level was found on hour 1, 3 and 6 in group A when compared to that of control levels of DNA; these increased values remained constant on hour $1(12.22 \mathrm{mg} / \mathrm{ml}), 3(12.22 \mathrm{mg} / \mathrm{ml})$ and 6 $(12.22 \mathrm{mg} / \mathrm{ml})$. A steep decline was noticed on hour $12(8.88 \mathrm{mg} / \mathrm{ml})$ (below normal value). From hour 12 onwards to the hour of 216, there was a decrease of DNA content and this decrease of DNA content is lower than that of normal values of control fish. The lowest amount of DNA $(5.55 \mathrm{mg} / \mathrm{ml})$ is present on hour 216 . DNA decreased from hour $1(16.66 \mathrm{mg} / \mathrm{ml})$ to $216(3.33 \mathrm{mg} / \mathrm{ml})$ of experimental period in fish of group B in comparison with controls (group b) $(9.89 \mathrm{mg} / \mathrm{ml}$ in hour 1). The level of DNA was found to be same on hour 1 $(16.66 \mathrm{mg} / \mathrm{ml})$ and $3(16.66 \mathrm{mg} / \mathrm{ml})$. It is interesting to note that the level of DNA gradually decreased from hour $3(16.66 \mathrm{mg} / \mathrm{ml})$ to day $9(3.33 \mathrm{mg} / \mathrm{ml})$. In group C there was an increase of DNA from hour 1 to 12 and decrease on hour 18 and 24 below normal values. There was a sudden increase of DNA from hour 24 (5.55 $\mathrm{mg} / \mathrm{ml})$ to $36(13.33 \mathrm{mg} / \mathrm{ml})$ of infection. Again there was a decrease by hour $48(8.88 \mathrm{mg} / \mathrm{ml}), 72(6.66$ $\mathrm{mg} / \mathrm{ml}), 96(5.55 \mathrm{mg} / \mathrm{ml})$ and $216(4.44 \mathrm{mg} / \mathrm{ml})$. DNA level reached at peak on hour $12(14.0 \mathrm{mg} / \mathrm{ml})$. The content of DNA is found to be equal on day $1(5.55 \mathrm{mg} / \mathrm{ml})$ and $4(5.55 \mathrm{mg} / \mathrm{ml})$ of infection. In group D, there was an increase of DNA from hour 1 to 48 and decrease on hour 72, 96 and 216, when compared to controls. These decreased values are found to be normal ( 72 hour) and below normal level (96 and 216 hour). The DNA content increased to peak value on hour $6(15.55 \mathrm{mg} / \mathrm{ml})$. All the experimental groups of fish showed decreased values of protein throughout the experimental period with slight alterations. The decreased values were found to be significant in groups A and B and non-significant in Group C. There was a significant increase of protein in group D. Interestingly the DNA level in experimental groups A and C of fish showed decreased values when compared with control (though it was statistically non-significant) There was a significant increase in the level of DNA in groups B and D.

Histopathology : The histopathological changes observed in the muscle (on day 3 ), indicate that infective and pathogenic bacteria, A. liquifaciens caused moderate to severe alteration in their architecture causing an ill effect on the important organs performing vital functions like bone protection, respiration, excretion, natural defense. The muscle of the teleost, like that of other vertebrates, is composed of long units called muscle fibers. The musculature is composed of S-shaped myonemes arranged side by side along both sides of the body. Histologically the lateral muscle fibers are composed of sarcoplasm, myofibrils, nuclei and sarcolemma. The existence of many nuclei within a single muscle fiber is a characteristic of striated muscle. Pathological alterations in the muscle may be observed as changes of striations, nuclear changes, phagocytosis and cellular reaction, cloudy swelling, hyaline degeneration and granular degeneration. The disappearance of distinct striations reflects changes in the sarcoplasm and is a clear sign of pathological condition in fish of groups A (10 ${ }^{2} \mathrm{CFU} /$ fish $)$ and B $\left(10^{-4} \mathrm{CFU} /\right.$ fish $)$. Experimental fish infected with low doses $\left(10^{-5}\right.$, group C and $10^{-6}$, group D) showed separation and degeneration of muscle, atrophy of muscle bundles and focal area necrosis. Splitting of 
muscle fibers and vacuolar degeneration were observed in fish treated with high doses (single dose of $10^{-2}$, group A and $10^{-4}$, group B).

The alterations in the level of protein and DNA in all the experimental groups of fish (from hour 1 to day 9) are sufficient indicators of the disease induction. The higher level of protein in muscle tissue in groups $\mathrm{A}, \mathrm{B}, \mathrm{C}$ and D suggest that the height of secondary immune response in L. rohita was dependent on repeated doses. Among the four single doses employed, the $10^{-6}$ dose is considered as the suitable dose to sensitize the immune system. These studies are similar to those of Lamers and Van Muiswinkel (1986), Karunasagar et al. (1991) and Newman (1993) who reported significant alterations in the profile of biochemical constituents using various antigen preparations of motile aeromonads in fish. Increased values of muscle protein was found on hour $6(70.0 \mathrm{mg} / \mathrm{ml})$ in fish treated with $10^{-2} \mathrm{CFU} /$ fish (group A), on hour $12(70.68 \mathrm{mg} / \mathrm{ml}), 18(70.34 \mathrm{mg} / \mathrm{ml})$ and $24\left(71.37 \mathrm{mg} / \mathrm{ml}\right.$ ) in fish treated with $10^{-5} \mathrm{CFU} /$ fish (group C), on hour $1(72.06 \mathrm{mg} / \mathrm{ml})$ to $216(72.06$ $\mathrm{mg} / \mathrm{ml}$ ) in fish treated with $10^{-6} \mathrm{CFU} /$ fish (group D) when compared with controls. The peak value of muscle protein was found on hour $6\left(73.10 \mathrm{mg} / \mathrm{ml}\right.$ ) in fish treated with $10^{-6} \mathrm{CFU} /$ fish (group D) when compared with other groups of fish. The muscle protein levels demonstrated dose dependent elevation in L. rohita during aeromoniasis. The grater value of muscle DNA was found from hour 1 to 6 in groups A and D, from hour 1 to 18 in group B and on hour 36 in group C; the peak value of DNA was found on hour 1 and $3(16.66 \mathrm{mg} / \mathrm{ml})$ in fish treated with $10^{-4} \mathrm{CFU} /$ fish. The alterations in protein and DNA level and histology in muscles of test fish indicate that the fish are prone to stress due to aeromoniasis causing marked physiological and histological changes. Marked biochemical alterations were induced in muscle tissue of Clarius batracus during insecticide treatment (Begum,2004). Decrease in protein content might be due to the impaired metabolism as suggested by Miyamoto (1976) and Murty and Devi (1982). Decreased protein and proteolytic changes may contributes to the elevation of aminoacids; the reduced level of protein might be due to reduction in protein synthesis as opined by Das and Bhattacharya (2006).The apparent decrease of total protein under high and low doses may be due to detoxification of enzymes and/or due to the metabolic utilization of ketoacids to gluconeogenesis as suggested by Neilson (1975). Durairaj and Selvarajan (1992) and Veeraiah and Durga Prasad (1998) also suggested that protein which serves as energy source during stress condition showed decreasing trend in gill, liver, muscle and brain tissues of Oerochromas mossambicus and Labeo rohita exposed to toxicants.

The histopathological alterations in the muscle of fish infected with varied single (low and high doses) doses indicate the pathogenic effect of infectious bacteria. The present observations like separation, degeneration and atrophy of muscle in fish infected with low doses (in groups C, D, E and F) and splitting of muscle fibers and degeneration of vacuoles in fish infected with high doses (in groups A and B) are similar to that of Sarkr and Gabr (1991), Nour and Amer (1995) and Elneneaki and Abuzinadah (2003) who reported degeneration, atrophy and splitting of muscle fibers in muscle of Tilapia nilotica exposed to diazinon and neopybuthrin, Clarias lazera (Nile cat fish) affected by hostathion insecticide contamination and Oreochromis spilurus effected by contra/insect 500/50 E.C. respectively. Huizinga et al. (1979) reported erosion of epidermis and dermis and severe necrosis of underlying musculature (in Micropterus salmoides infected with A. hydrophila) as observed in the present study. Parikh et al. (2010) also found degeneration, atrophy and necrosis of muscle fibers in freshwater fish, Oreocromus mossambicus exposed to various concentrations of an insecticide, dimethoate.

Acknowledgements : The author is grateful to Prof. V.Viveka Vardhani, Head of Department of Zoology for providing laboratory facilitates.

\section{References}

[1]. Adanir, D.O.R. and Turutoglu, H. (2007). Isolation and antibiotic susceptibility of Aeromonas hydrophila in a carp (Cyprinus carpio) Hatchery Farm. Bull. Vet. Inst. Pulawy. 51: 361-364.

[2]. Ansary, A., Haneef, R.M., Torres, J.L. and Yadav, M. (1992). Plasmids and antibiotic resistance in A. hydrophila. J. Fish Biol. 15: 191-196.

[3]. Aoki, T. (1999). Motile Aeromonads (Aeromonas hydrophila). In: Woo, P.T.K. and Bruno, D.W. (Eds.): Fish Diseases and Disorders. CABI Publishing, USA.

[4]. Begum, G. (2004). Carbofuran insecticide induced biochemical alterations in liver and muscle tissues of the fish Clarias batrachus (Linn.) and recovery response. Aquatic Toxicol., 66(1): 83-92.

[5]. Bullock, G.L., Conray, D.A. and Snieszko, S.F. (1971). Septicemic diseases caused by motile aeromonads and pseudomonads. In Snieszko, S.F. and Axelrod, H.R. (Eds). Diseases of Fishes. Book 2A: Bacterial Diseases of fishes. TFH publications, Neptune, New Jersey.

[6]. Cipriano, R.C. (2001). Aeromonas hydrophila and motile Aeromonad septicemias of fish. Fish Dis. Leaflet 68, United States department of the Interior fish and wildlife service. Division of Fishery Research, Washington, DC, pp.1-25.

[7]. Das, B.K. and Mukherjee, S.C. (1998). Pathology of black spot disease in fry and fingerlings of rohu; Labeo rohita (Ham), Geobioscience, 25: 102-104.

[8]. Das, S. and Bhattacharya, T. (2006). Impact of Water Pollution on Fish Physiology - A Study. J. Aquaculture, 14: 1-16.

[9]. Dixon, B.A. and Issvoran, G. (1993). Antibacterial drug resistance in Aeromonas spp. isolated from domestic goldfish and koi from California. J. World Aqua. Soc. 24: 102-104. 
[10]. Durairaj, S. and Selvarajan, V.R. (1992). Influence of Quinolophos, an organophosphorus pesticide on the biochemical constituents of the tissues of fish, Oerochromis mossambius. J. Environ. Biol. 13(3): 181-185.

[11]. Elnemaki, E. and Abuzinadah, O. (2003). Effect of contra/insect 500/50 E.C. on the histopathology of Oreochromis spilurus fish. Egypt. J. Aquat. Res. Fish. 29: 221-253.

[12]. Frerichs, G.N. (1989). Bacterial diseases of marine fish. The Vet. Rec. 125: 315 318.

[13]. Guz, L. and Kozinska, E. (2004). Antibiotic susceptibility of Aeromonas hydrophila and A. sobria isolated from farmed carp (Cyprinus carpio L.). Bull. Vet. Inst. Pulawy. 48: 391-395.

[14]. Holliman, A. (1993). The veterinary approach to trout. In: Brown, L. (Ed.). Aquaulture for veterinarians: fish husbandry and medicine. Oxford: Pergamon Press. pp. 223-247.

[15]. Huizinga, H.W., Esch, G.W. and Hazen, T.C. (1979). Histopathology of red-sore disease (Aeromonas hydrophila) in naturally and experimentally infected largemouth bass Micropterus salmoides. J. Fish Dis. 2: 263-277.

[16]. Karunasagar, I., Rosalind, G. and Karunasagar, I. (1991). Immunological responses of the Indian major carps to Aeromonas hydrophila vaccine. J. Fish. Dis. 14: 413-417.

[17]. Karunasagar, I., Sugumar, G. and Karunasagar, I. (1995). Virulence characters of Aeromonas sp. isolated from EUS-affected fish. In: SHARIF, M., ARTHUR, J.R., SUBASINGHE, R.P. (Ed.). Diseases in Asian Aquaculture II. Manila: Asian Fisheries Society, Fish Health Section, pp. 307-314.

[18]. Khardori, N. and Fainstein, V. (1988). Aeromonas and Plesiomonas as etiological agents. Ann. Rev. Microbiol. 42: 395-419.

[19]. Lakshmanaperumalswamy, P.,Thayumanavan, T., Subashkumar, R. (2005). Aeromonas hydrophila: A reemerging pathogen. In: Marine Microbiology. Facets and Opportunities: Ramaiah, N. (Ed.), pp.115-119.

[20]. Lamers, C.H.J. and W.B., Van Muiswinkel, 1986. Natural and acquired agglutinin to Aeromonas hydrophila in carp. Cyprinus carpio. Can. J. Fish Aquat. Sci. 43: 619-624.

[21]. Miyamoto, J. (1976). Degradation metabolism and toxicity of synthetic pyrethroid. Environ. Health Perspect, 14: 15-28.

[22]. Miyazaki, T., Kageyama, T., Miura, M., Yoshida, T. (2001). Histopathology of vieremia-associated ana-aki-byo in combination with Aeromonas hydrophila in color carp Cyprinus carpio in Japan. Dis. Aqua. Org. 44: 109-120.

[23]. Murty, A.S. and Devi, A.P. (1982). The Effect of Endosulfan and its Isomers on Tissue Protein, Glycogen and Lipids in the fish Channa punctata. Pesti. Biochem. Physiol. 17: 280-286.

[24]. Neilson, S. (1975). Osmoregulation. Effect of salinities and heavy metal. Fed. Proc. 33: 2137-2146.

[25]. Newman, S.G. (1993). Bacterial vaccines for fish. Ann. Rev. Fish Dis. 3: 145-185.

[26]. Nour, A. and Amer, A. (1995). Impairment of muscle performance in the Nile catfish Clarias lazera in response to hostathion insecticide contamination and/or gamma irradiation. J. Egypt. Ger. Soc. Zool. 18: 153-175.

[27]. Parikh, P.H., Rangrez, A., Bagchi, R.A. and Desai, B.N. (2010). Effect of Dimethoate on some histoarchitecture of Freshwater fish Oreocromis mossambicus (Peters, 1852), The Bioscan. 5(1): 55-58.

[28]. Pettibone, G.W., Mear, J.P. and Sampsell, B.M. (1996). Incidence of antibiotic and metal resistance and plasmid carriage in Aeromonas isolated from brown null head (Ictalurus nebulosus). Lett. Appl. Microbiol. 23: 234-240.

[29]. Ramasamy H., Chellam, B, Moon, Y., Kim, H., Kim, J. and Heo, M. (2009). Use of Herbal concoction in the therapy of Goldfish (Carassius auratus) infected with Aeromonas hydrophila. Bull. Vet. Inst. Pulawy. 53: 27-36.

[30]. Sahoo, P.K., Meher, P.K., Mahapatra, K.D., Saha, J.N., Jana, R.K. and Reddy, P.V.G.K. (2004). Immune responses in different full sib families of Indian major carp Labeo rohita exhibiting differential resistance to Aeromonas hydrophila infection. Aquaculture, 238: $115-125$.

[31]. Sakr, S. and Gabr. S. (1991). Ultrastructural changes induced by diazinon and neopybuthrin in skeletal muscles of Tilapia nilotica. Proc. Zool. Sco. A.R.E. 21: 1-14

[32]. Son, R., Rusui, G., Sahilah, A.M., Zamuri, A., Raha, A.R. and Salmah, I. (1997). Antibiotic resistance and plasmid profile of Aeromonas hydrophila isolates from cultured fish Tilapia (Tilapia mossambica). Lett. Appl. Microbiol.. 24: 479-482.

[33]. Swann, L. and White, M.R. (1989). Diagnosis and treatment of Aeromonas hydrophila infection of fish. Aquaculture extension Illinois-Indiana Sea Grant Program, pp.91-92.

[34]. Veeraiah, K. and Durga Prasad, M.K. (1998). Study on the toxic effects of cypermethrin (technical) on organic constituents of freshwater fish, Labeo rohita. Proc. Acad. Environ. Biol. 7(2): 143-148.

[35]. Vivekanandhan, G., Savithamani, K., Hatha, A.A.M. and Lakshmanaperumalsamy, P. (2002). Antibiotic resistance of Aeromonas hydrophila isolated from marketed fish and prawn of South India. Internat. J. Food Microbiol. 76: 165-168.

[36]. Yildiz, H., Bekean, S., Karasu Benli, A.C. and Akan, M. (2005). Some blood parameters in the eel (Anguilla anguilla) spontaneously infected with Aeromonas hydrophila. Israel J. Vet. Med. 60: 91-92.

Table 1: Protein $(\mathrm{mg} / \mathrm{ml})$ and DNA $(\mathrm{mg} / \mathrm{ml})$ content in the muscle, of experimental fish treated with Aeromonas liquifaciens @1 $10^{-2} \mathrm{CFU} / \mathrm{FISH}$ (group A), $10^{-4} \mathrm{CFU} / \mathrm{FISH}$ (group B), 10 $0^{-5} \mathrm{CFU} / \mathrm{FISH}$ (group C) and $10^{-6}$ CFU/FISH (group D) at different periods of infection and control (groups a,b,c and d). Values are expressed in mean derived from five observations.

\begin{tabular}{|c|c|c|c|c|c|c|c|c|c|c|c|c|c|c|c|c|}
\hline \multirow{3}{*}{$\begin{array}{l}\text { Hours of } \\
\text { Necropsy }\end{array}$} & \multicolumn{8}{|c|}{ Experimental groups } & \multicolumn{8}{|c|}{ Control groups } \\
\hline & \multicolumn{2}{|c|}{ Group A } & \multicolumn{2}{|c|}{ Group B } & \multicolumn{2}{|c|}{ Group C } & \multicolumn{2}{|c|}{ Group D } & \multicolumn{2}{|c|}{ Group a } & \multicolumn{2}{|c|}{ Group b } & \multicolumn{2}{|c|}{ Group c } & \multicolumn{2}{|c|}{ Groupd } \\
\hline & Protein & DNA & Protein & DNA & Protein & DNA & Protein & DNA & Protein & DNA & Protein & DNA & Protein & DNA & Protein & DNA \\
\hline 1 & 68.27 & 12.22 & 64.13 & 16.66 & 69.31 & 11.11 & 72.06 & 13.33 & 68.91 & 9.89 & 68.21 & 9.89 & 67.99 & 9.89 & 68.93 & 9.87 \\
\hline 3 & 68.62 & 12.22 & 62.41 & 16.66 & 67.93 & 12.00 & 72.75 & 13.33 & 68.89 & 10.00 & 68.00 & 10.01 & 67.98 & 10.06 & 68.93 & 10.00 \\
\hline 6 & 70.00 & 12.22 & 63.79 & 15.22 & 66.89 & 13.00 & 73.10 & 15.55 & 68.81 & 10.01 & 67.90 & 10.00 & 67.99 & 10.01 & 68.92 & 10.01 \\
\hline 12 & 66.89 & 8.88 & 63.20 & 14.66 & 70.68 & 14.00 & 71.72 & 11.11 & 68.90 & 10.01 & 67.80 & 10.00 & 67.98 & 10.01 & 68.93 & 10.02 \\
\hline 18 & 67.93 & 7.77 & 63.79 & 14.44 & 70.34 & 7.77 & 70.31 & 11.11 & 68.91 & 10.00 & 67.90 & 10.01 & 67.99 & 10.01 & 68.94 & 10.00 \\
\hline 24 & 66.55 & 8.88 & 64.13 & 11.11 & 71.37 & 5.55 & 70.34 & 11.11 & 68.90 & 9.98 & 68.00 & 9.99 & 67.97 & 10.00 & 63.93 & 10.01 \\
\hline 36 & 63.79 & 7.77 & 67.24 & 10.00 & 69.31 & 13.33 & 71.03 & 12.22 & 68.91 & 10.01 & 68.00 & 10.01 & 67.98 & 9.99 & 68.94 & 10.01 \\
\hline 48 & 62.41 & 8.88 & 67.58 & 5.55 & 68.96 & 8.88 & 71.03 & 13.33 & 68.92 & 10.01 & 67.8 & 10.01 & 67.99 & 10.01 & 68.92 & 10.01 \\
\hline 72 & 59.31 & 7.77 & 65.17 & 5.55 & 68.31 & 6.66 & 70.68 & 10.00 & 68.87 & 10.00 & 67.90 & 10.01 & 67.96 & 10.01 & 68.91 & 9.99 \\
\hline 96 & 59.25 & 7.77 & 63.10 & 4.44 & 68.27 & 5.55 & 71.72 & 5.55 & 68.91 & 10.01 & 67.90 & 10.00 & 67.99 & 10.02 & 68.89 & 10.00 \\
\hline 216 & 58.96 & 5.55 & 62.41 & 3.33 & 68.06 & 4.44 & 72.06 & 5.55 & 68.91 & 10.00 & 68.50 & 9.99 & 67.96 & 10.03 & 68.94 & 10.01 \\
\hline
\end{tabular}



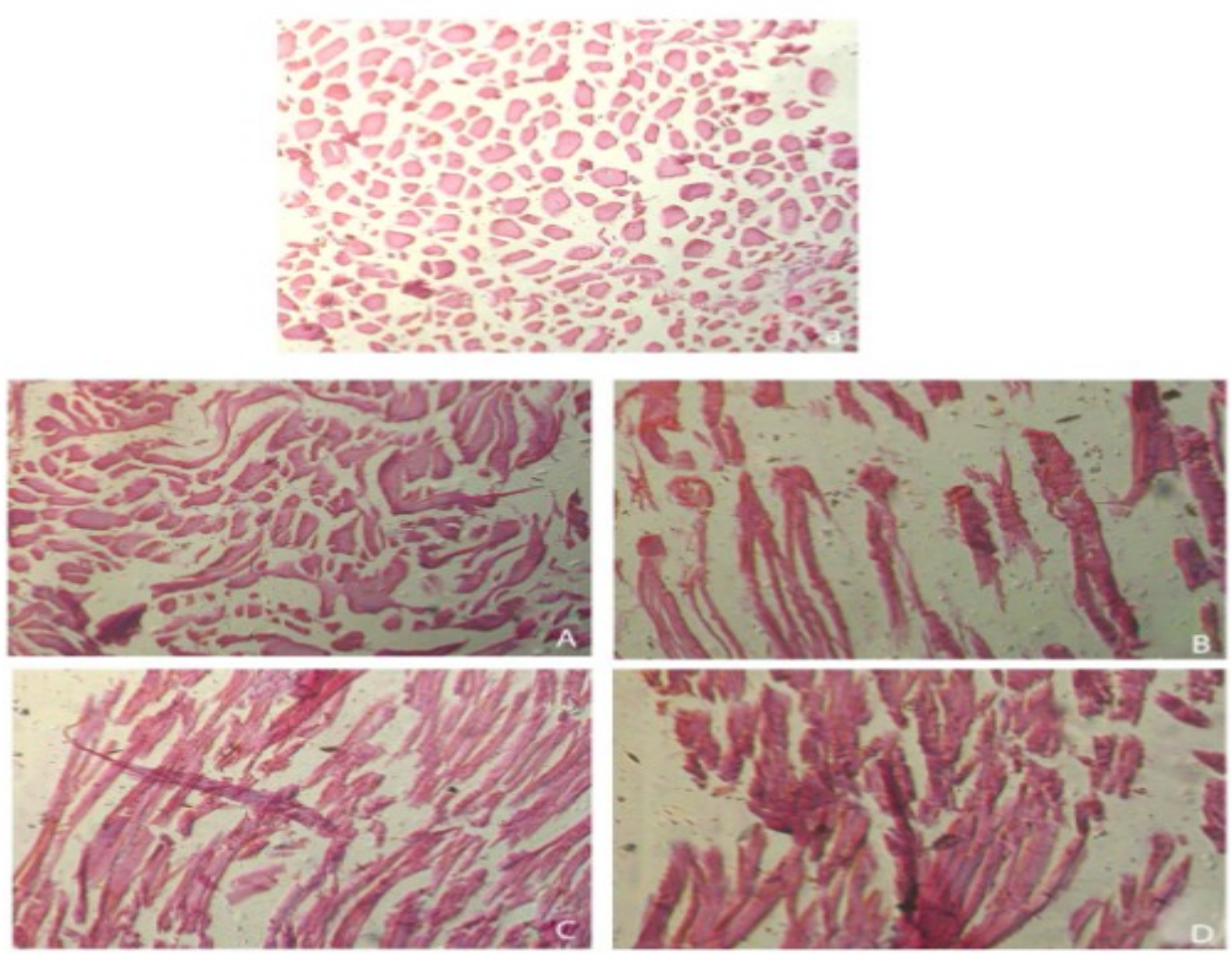

Figure : Showing muscle from control (a) and infected (A,B,C and D) fish.

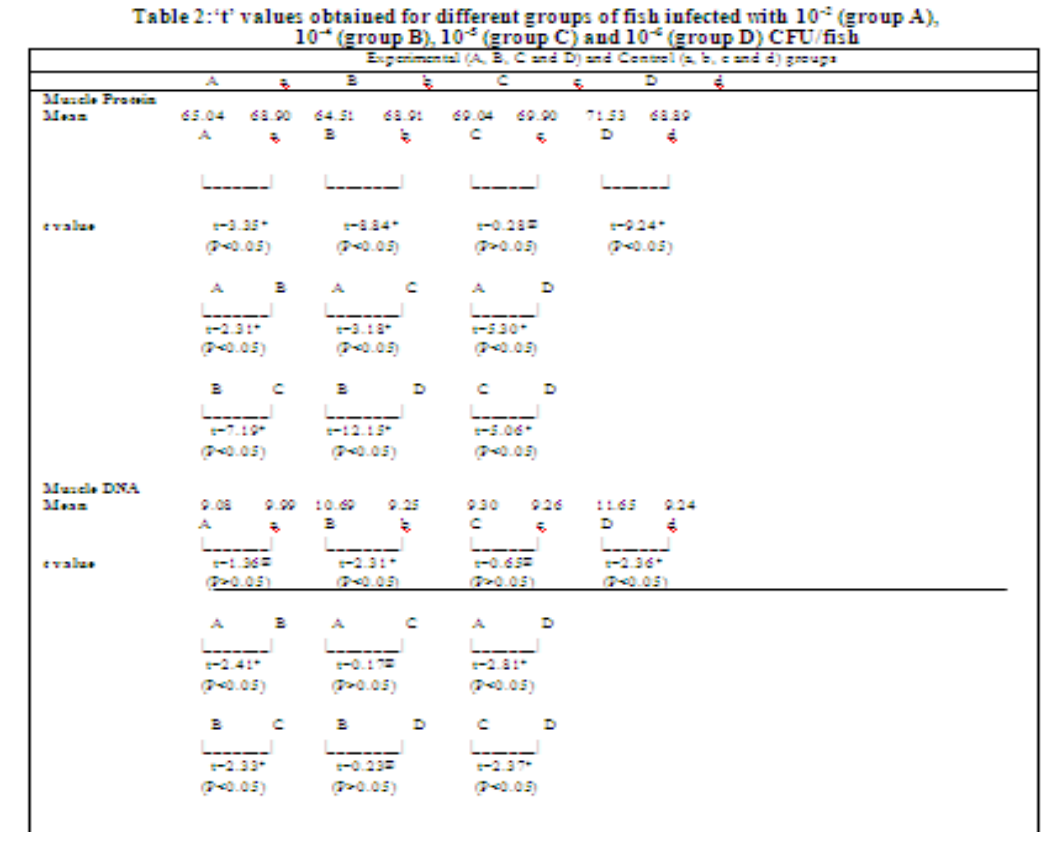

$\mathrm{P}$ value at $5 \%$ level of significance is 2.306

*Statistically significant values

${ }^{\circledR}$ Statistically non-significant values

Figure a: The normal structure of the muscle (10x)

Figure A : Degeneration, necrosis and atrophy of muscle bundles (20x)

Figure B : Necrosis and splitting of muscle fibers (20x)

Figure C : Atrophy of muscle bundles and splitting of muscle fibers (20x)

Figure D : The split muscle fibers found in clusters (20x) 